DOCUMENTATION OF MODEL INPUT AND OUTPUT VALUES FOR THE SIMULATION OF THE GROUNDWATER FLOW SYSTEM IN THE CRETACEOUS-AGE COASTAL PLAIN AQUIFERS OF SOUTH CAROLINA

By Bruce G. Campbell and Marijke van Heeswijk

Supplement to Water-Resources Investigations Report 96-4050

U.S. GEOLOGICAL SURVEY

Open-File Report 96-212

Prepared in cooperation with the

SOUTH CAROLINA DEPARTMENT OF NATURAL RESOURCES

WATER RESOURCES DIVISION and MOUNT PLEASANT WATERWORKS and SEWER COMMISSION

Columbia, South Carolina

1996 


\section{U.S. DEPARTMENT OF THE INTERIOR \\ BRUCE BABBITT, Secretary}

U.S. GEOLOGICAL SURVEY

Gordon P. Eaton, Director

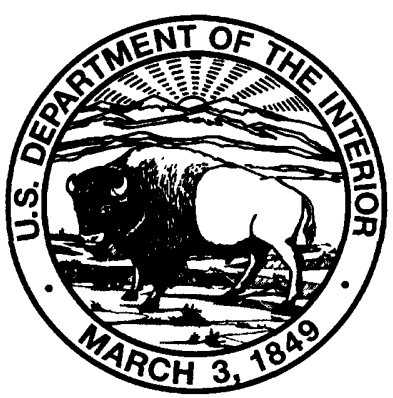

For additional information write to:

District Chief

U.S. Geological Survey

Stephenson Center-Suite 129

720 Gracern Road

Columbia, SC 29210-7651
Copies of this report can be purchased from:

U.S. Geological Survey

Earth Science Information Center

Open-File Reports Section

Box 25286, Mail Stop 517

Denver Federal Center

Denver, CO 80225 


\section{CONTENTS}

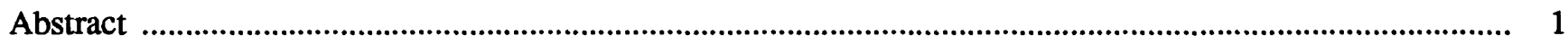

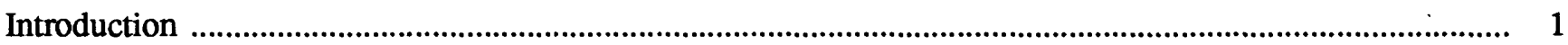

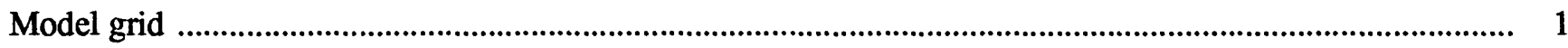

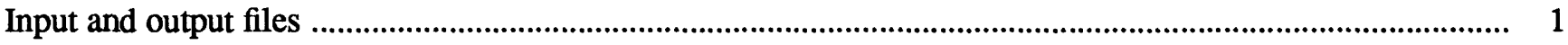

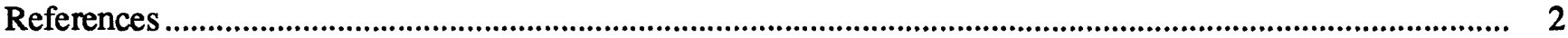

\section{TABLE}

1. File name, FORTRAN unit number, file size, and description of input and output files for the Cretaceous-age aquifer ground-water flow model 
[Blank Page] 


\title{
Documentation of model input and output values for the simulation of the ground-water flow system in the Cretaceous-age Coastal Plain aquifers of South Carolina
}

\author{
By Bruce G. Campbell and Marijke van Heeswijk
}

\section{Abstract}

This report and the attached $31 / 2$-inch diskette contain, in compressed format, the data sets for the model of ground-water flow in the Cretaceous-age Coastal Plain aquifers of South Carolina. The data sets can be uncompressed using a program provided with this report. The uncompressed files require approximately 3.7 megabytes of disk space on an IBM-compatible microcomputer $^{1}$ using the MS-DOS operating system. All files are in American Standard Code for Information Interchange format.

\section{INTRODUCTION}

A four-layer digital model of the groundwater system of the Cretaceous-age Coastal Plain aquifers of South Carolina was developed using the MODFLOW program by McDonald and Harbaugh (1988). Results of the study are described in a report by Campbell and van Heeswijk (in press). Although that report summarizes the data input to the model, detailed documentation of model input and model output has not been published. This report, which is a supplement to the report by Campbell and van Heeswijk (in press), provides detailed, electronic documentation of the model data.

\footnotetext{
${ }^{1}$ Use of trade names in this report are for identification purposes only and does not constitute endorsement by the U.S. Government.
}

\section{MODEL GRID}

The model grid is presented in figure 5 of Campbell and van Heeswijk (in press). The variable-cell-size grid is oriented northeast - southwest and consists of 115 rows and 127 columns, and covers an area of 39,936 square miles.

\section{INPUT AND OUTPUT FILES}

The input files for the Cretaceous-age aquifer model were developed on an IBM- compatible microcomputer operating under MS-DOS version 3.3. The files were then compressed so they could fit on a single diskette. The compression program produced a single file that contains all input and output files.

The diskette included with this report contains a copy of this text (README.DOC) and the library of compressed files (FILES.EXE). The decompression program is provided by PKWARE, Inc., 9025 N. Deerwood Drive, Brown Deer, Wisconsin. The library can be uncompressed by typing FILES.EXE and pressing enter. The decompressed files will be the same as the original MS-DOS files and will consist of text characters represented according to the American Standard Code for Information Interchange.

Files for the Cretaceous-age aquifer model are on a high-density, double-sided, 3 1/2-inch diskette with a capacity of 1.44 megabytes. The root directory on the diskette contains the file FILES.EXE that contains the input and output files for the Cretaceous-age aquifer flow model, and the file README.DOC. The compressed file 
can be uncompressed and form all input files, output file, and documentation.

The MODFLOW ground-water flow-model program runs on a variety of computers, but procedures for opening input data files are different for various computers, operating systems, and FORTRAN compliers. This report does not contain the MODFLOW model code, procedures for compiling MODFLOW, or procedures for using the model data sets on specific FORTRAN unit numbers.

The model input files presented are for a transient simulation. Data presented in the model are in units of feet and days. Input file names are presented in table 1 . The output file is named MOD.OUT.

\section{REFERENCES}

Campbell, B.G., and van Heeswijk, M., in press, Ground-water hydrology, historical wateruse, and simulated ground-water flow in the Cretaceous-age Coastal Plain aquifers near Charleston and Florence, South Carolina: U.S. Geological Survey Water-Resources Investigation Report 96-4050.

McDonald, M.G., and Harbaugh, A.W., 1988, A modular three-dimensional finite-difference ground-water flow model: U.S. Geological Survey Techniques of Water-Resources Investigations, book 6 , chap. A1, $586 \mathrm{p}$.

TABLE 1. File name, FORTRAN unit number, file size, and description of input and output files for the Cretaceous-age aquifer ground-water flow model

[-, not applicable]

\begin{tabular}{lcrl}
\hline File name & $\begin{array}{c}\text { FORTRAN } \\
\text { unit }\end{array}$ & \multicolumn{1}{c}{$\begin{array}{c}\text { Size } \\
\text { (bytes) }\end{array}$} & \multicolumn{1}{c}{ Description of file } \\
\hline bas.dat & 5 & 335,162 & Basic package data \\
bcf.dat & 11 & 930,479 & Block-centered flow package data \\
rch.dat & 18 & 59,887 & Recharge package data \\
riv.dat & 14 & 18,628 & River package data \\
wel.dat & 13 & 815,537 & Well package data \\
pcg.dat & 15 & 102 & Solver package data \\
oc.dat & 19 & 1,530 & Output control package data \\
mod.out & -- & $1,512,478$ & Model output file \\
\hline
\end{tabular}

